\title{
Creative Research on Rural Tourism Products Based on TAIM Model - Take Xintian Village of Quanzhou County as an Example
}

\author{
Ying Liu ${ }^{1, *}$, Rong Wang ${ }^{1}$ \\ ${ }^{1}$ College of Tourism \& Landscape Architecture, Guilin University of Technology, Guilin ,541000, China
}

\begin{abstract}
At present, the development of rural tourism in China is faced with the embarrassment of "small scale, flat resources" and the lack of creative planning methods, which leads to the serious problem of the simplification and homogeneity of rural tourism products. From the perspective of cultural creativity, this paper puts forward TAIM model of rural tourism product development, and takes "Guangxi district-level rural tourism poverty alleviation village" Xintian village of Quanzhou county as an example to make an empirical analysis of this model, in order to provide some inspiration for the development of rural tourism products in China.
\end{abstract}

\section{Introduction}

With the development of social economy and the increase of "small holidays", rural tourism has developed rapidly. It is predicted through big data deduction that the number of rural tourism visitors is expected to reach 3 billion in 2025. Rural tourism in China enjoys a good momentum of development, but also faces some problems. In a rush of rural tourism, most of them ignore the exploration of rural characteristics, which makes the tourism products in rural areas with "small scale and flat resources" become homogeneous and unitary. The China rural tourism development index report released in 2016 showed that about 80 percent of rural tourism destinations are ultimately unsustainable or unprofitable. In view of the lack of large landscape resources in rural areas, how to creatively develop their rural tourism products to achieve sustainable development is the problem to be solved in this paper.

\section{The theoretical basis and model construction of TAIM model}

\subsection{The theoretical basis of the TAIM model}

With the transformation and upgrading of tourism, the tourism market needs more diversification and in-depth innovation to meet the needs of tourists and promote the development of regional tourism economy. Cultural and creative tourism industry, as the product of the integration of tourism and cultural and creative industries, can expand the extension of tourism resources and improve the connotation of tourism products ${ }^{[1-3]}$. At present, there is no clear definition of creative tourism products in the academic circle. The author believes that creative tourism products are based on rural tourism resources and integrate creative elements into the design of rural tourism products to design new tourism products with educational and experiential characteristics ${ }^{[4]}$. With the advent of the era of deep experience, the development of rural tourism in China has encountered major problems of product transformation and upgrading, especially the "plain resources" in the countryside. This requires more innovative thinking to explore the characteristics of rural areas and design innovative tourism products with high experience and participation.

\subsection{Construction of the TAIM pattern}

Based on the above theoretical analysis and the characteristics of rural creative products, the author puts forward the creative development model of "TAIM" rural tourism products.As shown in the Figure 1.

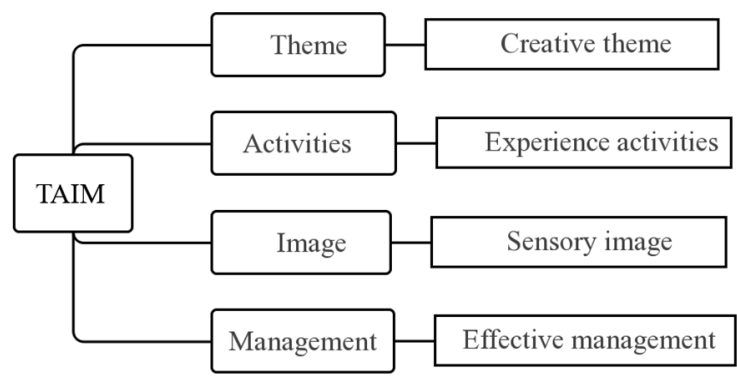

Fig. 1. TAIM schema connotation

First, the creative theme is to find out the unique selling points of rural tourism products. The theme positioning strategy of tourism resort with scarce resources should follow two principles: one is to objectively evaluate its own resources and not to be arrogant; The other is to make the best of the advantages 
and avoid the disadvantages, analyze the competition and cooperation with the surrounding scenic spots and market demand, so as to determine the theme positioning of the featured products. Second, the design of experience activities should focus on creative themes, identify different sub-themes based on rural characteristic resources, and use creative thinking to design some experience activities with high participation and strong experience. Third, sensory image design is the same as experience activities, is also the means and ways of rural creative tourism product development. Mainly from the visual, taste, hearing, smell, touch and other aspects of creative product design, to deepen the experience of visitors. Fourth, effective management is built on the basis of creative themes, experience activities and sensory images, which is the support and feedback link of rural creative tourism product development.

In developing tourism product innovation in rural areas, we should consider these four factors, take the theme of creativity as the centripetal force of rural tourism products, build the attraction of rural tourism products with experience activities, strengthen the competitiveness of rural tourism products with sensory images, and effectively manage and support the formation of rural tourism products.

\section{Empirical study -a case study on the development of rural tourism products in Xintian village,Quanzhou county}

\subsection{The development of rural tourism in Xintian village}

Tourism resources are the material basis of tourism development and tourism development. Through on-site investigation of tourism resources that can be developed and utilized in Xintian village, according to the classification standards of "tourism resources survey, classification and evaluation (GB/ t18972-2017)" and tourism resources evaluation index, the tourism resources of Xintian village are sorted out and classified.

Table 1. Evaluation table of main tourist resources or scenic spots in Xintian village

\begin{tabular}{|c|c|c|}
\hline Grade & Quantity & $\begin{array}{l}\text { Main tourist resource } \\
\text { monomer or scenic spot }\end{array}$ \\
\hline $\begin{array}{c}\text { Second } \\
\text {-level }\end{array}$ & 5 & $\begin{array}{c}\text { Hehua fish breeding base, } \\
\text { silver cod, vinegar duck, gold } \\
\text { pagoda flower, black carp } \\
\text { Hehua fish }\end{array}$ \\
\hline One & 23 & $\begin{array}{c}\text { Cold spring water, irrigation, } \\
\text { Wanshan mountain caves, } \\
\text { ancient bridge in one hundred, } \\
\text { the source east ferry, } \\
\text { waterfalls, bamboo crafts, } \\
\text { orange orchards, lotus pond, } \\
\text { waterfront bamboo, peach } \\
\text { blossom, peak cluster, brewed } \\
\text { rice wine, orange, red pepper, } \\
\text { bamboo shoots, acid red }\end{array}$ \\
\hline
\end{tabular}

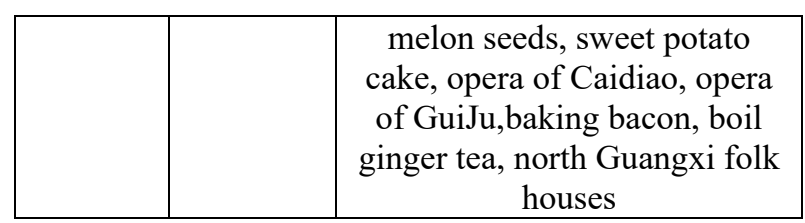

It can be seen from Table 1 that:(1) Xintian village is short of excellent tourism resources, and the overall level of resources is not high. (2) Xintian village water scenery resources, vegetation landscape resources, folk custom resources and agricultural product resources is serious, and the grass carp is a peculiar place for Quanzhou, fleshy delicate, cartilage, no smell, high protein content, rich nutrition, was a dynasty era of royal tribute ${ }^{[5]}$, dig deep should be made for these resources to find creative tipping point and creative development. (3)Relying on rural resources, Xintian village has initially developed part of the leisure agricultural tourism resources, designed the rural picking, fishing and other tourism projects, leisure tourism has begun to take shape. However, these developed tourism projects and products lack creativity and characteristics ${ }^{[6]}$, which need further exploration and planning.

\subsection{Practical application of TAIM rural tourism product development model}

\subsubsection{Creative theme design of rural creative tourism products}

Xintian village has a certain amount of tourism resources, but tourism resources do not form a strong attraction. Therefore, tourism area is suitable for the development mode of resource integration and innovation. In addition, with the development of modern society, the pace of life of urban residents is getting faster and faster, and the work pressure is getting bigger and bigger. Physical and mental fatigue and sub-health are becoming very common. They hope that through healthy conditioning to achieve physical and mental health needs are increasingly strong. From the perspectives of cultural creativity, resource integration and tourism demand, this paper focuses on the theme of tourism products of Xintian village as "all-round health maintenance". Combined with the theme, creative thinking can be used to design the farming culture health, waterfront leisure health, folk culture health, food culture health and other experience activities rich in culture, experience, health and creativity, so as to make Xintian village a creative rural tourism destination integrating rural leisure, health and vacation.

\subsubsection{Creative tourism product experience activity design}

The design of the experience activities should focus on the creative theme. According to different sub-themes, we can develop and design some activity projects with high participation, strong experience and fitting to the sub-theme. According to the creative theme of "all-round health preservation" and the sub-theme of farming culture experience, food culture experience and folk culture experience, the creative tourism product experience 
project of Xintian village is designed by using rural tourism resources. Specific experience activities are shown in Table 2 below.

Table 2. Creative tourism product experience project of Xintian village

\begin{tabular}{|c|c|c|}
\hline $\begin{array}{c}\text { Creative } \\
\text { theme }\end{array}$ & $\begin{array}{c}\text { Experience } \\
\text { activity theme }\end{array}$ & $\begin{array}{c}\text { Experience } \\
\text { activities }\end{array}$ \\
\hline \multirow{4}{*}{$\begin{array}{c}\text { All-round } \\
\text { Health }\end{array}$} & $\begin{array}{c}\text { Farming culture } \\
\text { and health } \\
\text { preservation }\end{array}$ & $\begin{array}{c}\text { "Health farm" } \\
\text { "Fragrance } \\
\text { orchard" } \\
\text { and so on }\end{array}$ \\
\cline { 2 - 3 } & $\begin{array}{c}\text { Food culture and } \\
\text { health preservation }\end{array}$ & $\begin{array}{c}\text { "Folk food } \\
\text { experience } \\
\text { hall" "Organic } \\
\text { restaurant" and } \\
\text { so on }\end{array}$ \\
\cline { 2 - 3 } & $\begin{array}{c}\text { Waterfront leisure } \\
\text { health } \\
\text { preservation }\end{array}$ & $\begin{array}{c}\text { "Heart fishing" } \\
\text { "Bathing } \\
\text { bamboo forest" } \\
\text { and so on }\end{array}$ \\
\cline { 2 - 3 } & $\begin{array}{c}\text { Folk culture health } \\
\text { preservation }\end{array}$ & $\begin{array}{c}\text { "Folk culture } \\
\text { festival" } \\
\text { experience } \\
\text { workshop" and } \\
\text { so on }\end{array}$ \\
\hline
\end{tabular}

\subsubsection{Sensory image design of rural creative tourism products}

The sensory image design of rural tourism destination determines the tourists' satisfaction and return rate, determines the reputation of scenic spots, and is an important factor to attract tourists. Sensory image design should give full consideration to the needs of customers and their own resources, comprehensively stimulate tourists' vision, hearing, smell, taste and touch, and deepen their experience ${ }^{[7]}$. Taking Xintian village as an example, the specific development methods are as follows:

First of all, Xintian village can take green as the standard color of the scenic spot, which echoes with the ecological health green and is widely used in the interpretation signs and tourist souvenirs of the scenic spot to highlight the theme image. Second, in terms of auditory experience, the sound of water and birds singing in the countryside can be appropriately amplified, so that visitors can experience the real rural environment. Third, in terms of taste experience, a variety of health food with local characteristics are developed with the help of the unique local livestock and crop resources to arouse tourists' appetite. Fourth, in terms of smell, the image of smell is mainly to experience the natural atmosphere of farmland environment and forest environment, so as to cultivate the feelings of tourists. Fifth, the products of tactile experience are mainly designed around the farming experience, so that tourists can participate in the experience and improve the pleasure of sightseeing.

\subsubsection{Effective management of rural creative tourism products}

Effective management is the supporting link of rural tourism product development, which is conducive to the perfection of rural tourism product design and ensure the smooth development and sales of rural tourism products. The specific ways are as follows. First,Strengthen the training and introduction of rural innovative talents. As knowledge-intensive products, creative tourism products in rural areas have a strong demand for innovative talents. Xintian village tourism development has just started, to create creative tourism products, we must vigorously train and introduce a number of creative tourism talent. Second, pay attention to the creative marketing of rural tourism products $^{[8]}$. Xintian village can rely on cultural and creative industries to promote the marketing of rural tourism products. WeChat official account and short video platform are used to implant rural tourism product marketing and expand the audience of rural tourism products through continuous network publicity.

\section{Conclusion}

TAIM rural creative tourism product development model will be creative element into the rural tourism product development, and on this basis to develop rural tourism products theme, creative product design, help to improve the quality of the rural tourism products and taste, rich rural tourism product type, to meet the demand of tourists deep-seated needs, increase the appeal to tourists, is the realization of rural tourism sustainable development of a breakthrough.

\section{Acknowledgement}

Thanks for the help of the fund: The National Social Science Foundation of China Western Project: Research on the Protection and Development of Cultural Heritage of Geographical Names in Lingnan Area under the Background of Urbanization.(No.17XSH006).

\section{References}

1. G.A.Richards, j. Wilson,T.M.,27(2006).

2. D. Xu, Q. Wei, Yunnan. Unive. Fina. Eco,27(2011).

3. H.Wang. J .Tour,30(2005).

4. X.Sheng .Beijing Agric,2(2014)

5. L .Xu: Annals Quanzhou county, (Guangxi people's pub house, 1998)

6. F. Lin. Taiwan. Agric. Explo,2(2019)

7. C. Xie,Forest Econ Issues,35(2015)

8. H.Zhao,W. li .Shanxi Normal Univer,30(2016) 